\title{
Measurement of cytoplasmic pH of the alkaliphile Bacillus lentus C-125 with a fluorescent pH probe
}

\author{
Rikizo Aono, Masahiro Ito and Koki Horikoshi
}

Author for correspondence: Rikizo Aono. Fax: +81 45924 5819. e-mail : raono@bio.titech.ac.jp

Department of Bioengineering, Faculty of Bioscience and Biotechnology, Tokyo institute of Technology, Nagatsuta 4259, Yokohama 226, Japan

\begin{abstract}
A method was established to measure the cytoplasmic pH of the facultative alkaliphilic strain, Bacillus lentus C-125. The bacterium was loaded with a pH-sensitive fluorescent probe, 2', 7'-bis-(2-carboxyethyl)-5 (and -6)carboxyfluorescein (BCECF), and cytoplasmic pH was determined from the intensity of fluorescence of the intracellular BCECF. The activity of the organism to maintain neutral cytoplasmic pH was assessed by measuring the cytoplasmic pH of the cells exposed to various pH conditions. The cytoplasmic pH maintenance activity of $\mathrm{C}-125$ increased with increasing culture $\mathrm{pH}$, indicating that the activity was regulated in response to the culture pH.
\end{abstract}

Keywords: alkaliphile, Bacillus lentus, cytoplasmic $\mathrm{pH}, \mathrm{pH}$ homeostasis

\section{INTRODUCTION}

The facultative alkaliphile, Bacillus lentus C-125, grows between $\mathrm{pH} 6.8$ and 10.8 (Aono \& Horikoshi, 1983; Aono, 1995; Aono et al., 1995). It has been reported that a $\Delta \psi$-dependent $\mathrm{Na}^{+} / \mathrm{H}^{+}$antiporter in the cell membrane helps to maintain the cytoplasmic $\mathrm{pH}$ around neutrality. This activity is increased with increasing culture $\mathrm{pH}$ (Kitada et al., 1994). In addition, structural components of the cell surface of the organism are changed and respiratory activity increases in response to the culture $\mathrm{pH}$ (Aono \& Horikoshi, 1983; Aono, 1985; Aono et al., 1995, 1996).

Microbial cytoplasmic $\mathrm{pH}$ has been measured from the distribution of weak acids or weak bases after equilibration of the electrolytes between intracellular and extracellular compartments (Zilverstein et al., 1982; Padan \& Schuldiner, 1986) or absorption or fluorescence intensity of a $\mathrm{pH}$-sensitive dye trapped intracellularly (Dencher et al., 1986; Tsujimoto et al., 1988). However, distribution of weak electrolytes might be affected by a high density of negative charges fixed on the cell surface of alkaliphiles (Aono \& Horikoshi, 1983). Moreover, the cytoplasmic ionic strength of the alkaliphile is unknown and dissociation constants of weak electrolytes depend on ionic strength. If the dissociation constants differ between the cytoplasm and external milieu, accurate cytoplasmic $\mathrm{pH}$ cannot be calculated theoretically. We therefore tried to measure cytoplasmic

Abbreviations: BCECF, 2',7'-bis-(2-carboxyethyl)-5 (and 6)-carboxyfluorescein; BCECF-AM, acetoxymethyl ester of BCECF.
$\mathrm{pH}$ of $\mathrm{B}$. lentus $\mathrm{C}-125$ using the $\mathrm{pH}$-sensitive fluorescent probe, 2',7'-bis-(2-carboxyethyl)-5 (and 6)-carboxyfluorescein (BCECF). BCECF has previously been used to measure cytoplasmic $\mathrm{pH}$ of eukaryotic or prokaryotic cells (Tsujimoto et al., 1988; Molenaar et al., 1991; Futsaether et al., 1993).

In this report we describe a method to load the alkaliphile with BCECF, measurement of the cytoplasmic $\mathrm{pH}$ from the fluorescence intensity of the BCECF and determination of the level of cytoplasmic $\mathrm{pH}$ homeostatic activity in response to the culture $\mathrm{pH}$.

\section{METHODS}

Bacterial strains. B. lentus C-125 (FERM 7344; Fermentation Research Institute, Agency of Industrial Science and Technology, Ministry of International Trade and Industry, Tsukuba, Japan) (Aono \& Horikoshi, 1983) was used. A neutrophilic strain, Bacillus subtilis GSY1026 (Aono \& Horikoshi, 1983), was used as a reference strain.

Media and growth conditions. The alkaliphilic bacterium was grown aerobically at $37^{\circ} \mathrm{C}$ in a medium consisting of (per litre deionized water): $\mathrm{K}_{2} \mathrm{HPO}_{4}, 13.7 \mathrm{~g} ; \mathrm{KH}_{2} \mathrm{PO}_{4}, 5.9 \mathrm{~g}$; citric acid, $0.34 \mathrm{~g}$; $\mathrm{MgSO}_{4} .7 \mathrm{H}_{2} \mathrm{O}, 0.05 \mathrm{~g}$; glucose, $10 \mathrm{~g}$; peptone, $5 \mathrm{~g}$; yeast extract, $1 \mathrm{~g}$; and $\mathrm{Na}_{2} \mathrm{CO}_{3}, 10.6 \mathrm{~g}$. The $\mathrm{pH}$ of this medium was about 10 (Aono, 1985). B. subtilis GSY1026 was grown in Luria broth at pH 7 (Miller, 1972). When it was necessary to keep the $\mathrm{pH}$ constant during growth, bacteria were grown in a vessel equipped with a $\mathrm{pH}$-stat apparatus (Aono et al., 1995).

Loading of cells with BCECF. (i) B. lentus C- 125 was grown in $200 \mathrm{ml}$ of the alkaline medium in which the $\mathrm{pH}$ was maintained at 10 . Bacteria in stationary phase $\left(O D_{660}=2\right)$ were harvested by centrifugation $\left(6000 \mathrm{~g}, 4^{\circ} \mathrm{C}, 12 \mathrm{~min}\right)$. The 
cells were washed with $0 \cdot 1 \mathrm{M} \mathrm{NaCl} / 0 \cdot 1 \mathrm{M} \mathrm{KCl} / 0 \cdot 1 \%$ glucose $/ 0 \cdot 1 \mathrm{M} \mathrm{CHES} / \mathrm{NaOH}(\mathrm{pH} 9 \cdot 1)$ and resuspended in $8 \mathrm{ml}$ of the same buffer. A sample $(80-160 \mu \mathrm{l})$ of $1 \mathrm{mM}$ lipophilic acetoxymethyl ester of BCECF (BCECF-AM) dissolved in DMSO was added to the suspension, which was then gently stirred at $4{ }^{\circ} \mathrm{C}$ in the dark for $2.5 \mathrm{~h}$. The cells were harvested by centrifugation, resuspended in $100 \mathrm{ml}$ CHES buffer and incubated at $37^{\circ} \mathrm{C}$ for $45 \mathrm{~min}$ to remove most of BCECF loaded into the cells. The cells were recovered by centrifugation and resuspended in buffer. The cell suspension was kept on ice until used.

(ii) B. subtilis GSY1026 was grown in the neutral medium, with $\mathrm{pH}$ maintained at $7 \cdot 0$. The cells were washed with $0 \cdot 1 \mathrm{M}$ $\mathrm{NaCl} / 0 \cdot 1 \mathrm{M} \mathrm{KCl} / 0 \cdot 1 \%$ glucose $/ 0 \cdot 1 \mathrm{M}$ TES $/ \mathrm{NaOH}(\mathrm{pH} 7 \cdot 0$ ) and resuspended in the buffer. The cells were loaded with BCECF at $\mathrm{pH} 7 \cdot 0$, as described above. The cells loaded with BCECF were resuspended in TES buffer and kept on ice until used.

Measurement of fluorescence intensity of BCECF-loaded cells. The suspension of the BCECF-loaded cells was diluted 50 -fold with $0 \cdot 1 \mathrm{M} \mathrm{NaCl} / 0 \cdot 1 \mathrm{M} \mathrm{KCl} / 0 \cdot 1 \%$ glucose $/ 0 \cdot 1 \mathrm{M}$ TES/NaOH $(\mathrm{pH} 6 \cdot 0-8 \cdot 6)$ or $0 \cdot 1 \mathrm{M} \mathrm{NaCl} / 0 \cdot 1 \mathrm{M} \mathrm{KCl} / 0 \cdot 1 \%$ glucose $/ 0 \cdot 1 \mathrm{M}$ glycine $/ \mathrm{NaOH}(\mathrm{pH} 8 \cdot 0-12 \cdot 0)$. The cells were incubated at $37^{\circ} \mathrm{C}$ for $30 \mathrm{~min}$.

A fluorescence excitation spectrum of intracellular BCECF was recorded using an F-2000 fluorescence spectrophotometer (Hitachi) with double monochromators. BCECF was excited at $430-520 \mathrm{~nm}$ and the emission was measured at $535 \mathrm{~nm}$. The slit width for both the excitation and emission monochromators was $10 \mathrm{~nm}$. Samples were stirred and maintained at $37^{\circ} \mathrm{C}$ during the fluorescence measurement. Immediately after the fluorescence measurement, the extracellular $\mathrm{pH}$ of the suspension was measured with a glass electrode and the suspension was centrifuged at $6000 \mathrm{~g}$ for $5 \mathrm{~min}$. Fluorescence intensity of extracellular BCECF was measured in the supernatant.

Estimation of cytoplasmic pH. Two parameters, the fluorescence intensity of BCECF at $510 \mathrm{~nm}\left(F_{510}\right)$ and a ratio of the intensities at 510 and $450 \mathrm{~nm}\left(\operatorname{Ratio}_{510 / 450}\right)$, were used as measures of cytoplasmic $\mathrm{pH}$ (Molenaar et al., 1991; Futsaether et al., 1993). The ionophore gramicidin was used to relate these parameters to cytoplasmic $\mathrm{pH}$ for each batch of the cell suspension. Bacteria loaded with BCECF and washed at pH 9.1 as described above were resuspended in TES (pH 6.0-8.6) or glycine ( $\mathrm{pH} 8 \cdot 0-12 \cdot 0$ ) buffers (described above) containing $20 \mu \mathrm{M}$ gramicidin. After the cell suspension $\left(\mathrm{OD}_{660}=2\right)$ had been incubated at $37^{\circ} \mathrm{C}$ for $30 \mathrm{~min}$, the fluorescence intensity of the suspension was measured. Cytoplasmic $\mathrm{pH}$ was taken to be equal to the extracellular $\mathrm{pH}$ measured with a glass electrode. A calibration curve of $F_{510}$ or Ratio R10/450 was constructed, using the method of least squares, in every experiment from which the cytoplasmic $\mathrm{pH}$ of the sample was estimated.

Materials. Gramicidin D and BCECF-AM were purchased from Sigma.

\section{RESULTS}

Loading BCECF into $B$. lentus C-125 cells using BCECF-AM

BCECF was loaded into $B$. lentus $\mathrm{C}-125$ cells using the non-fluorescent and membrane-permeable derivative, BCECF-AM. Intracellular BCECF-AM is converted to the strongly fluorescent and charged dye BCECF by cytoplasmic esterases (Futsaether et al., 1993). C-125 cells did not take up BCECF when incubated with BCECF itself.

(i) Effect of incubation temperature. B. lentus $\mathrm{C}-125$ cells were incubated in $0 \cdot 1 \mathrm{M} \mathrm{NaCl} / 0 \cdot 1 \mathrm{M} \mathrm{KCl} / 0 \cdot 1 \%$ glucose $/ 5 \mu \mathrm{M}$ BCECF-AM $/ 0 \cdot 1 \mathrm{M}$ Tricine $/ \mathrm{NaOH}(\mathrm{pH}$ 8.5 ) at temperatures between 0 and $30^{\circ} \mathrm{C}$ for $2.5 \mathrm{~h}$. Loading of BCECF into the cells was significantly dependent on the incubation temperature. Maximum loading occurred between 5 and $10^{\circ} \mathrm{C}$. Less than $20 \%$ of the maximum fluorescence intensity was observed at $0^{\circ} \mathrm{C}$ or at temperatures higher than $20^{\circ} \mathrm{C}$. This may be due to an effect of temperature on permeation of BCECF-AM into the cells, enzymic hydrolysis of BCECF-AM to BCECF or leakage of BCECF from the cells. The incubation temperature was the most important factor in optimizing loading the cells with BCECF.

(ii) Incubation pH. We next examined the effect of the incubation $\mathrm{pH}$ on BCECF-AM during loading of the C-125 cells with BCECF. The cells grown at $37^{\circ} \mathrm{C}$ and $\mathrm{pH} 10$ were incubated in $0 \cdot 1 \mathrm{M}$ Good buffer containing $5 \mu \mathrm{M}$ BCECF-AM, $0.1 \mathrm{M} \mathrm{NaCl}, 0.1 \mathrm{M} \mathrm{KCl}$ and $0.1 \%$ glucose at $4{ }^{\circ} \mathrm{C}$ for $2.5 \mathrm{~h}$. The cells recovered by centrifugation were assayed for fluorescence intensity of BCECF. BCECF loading was optimal at $\mathrm{pH} 9$ and was at least $30 \%$ less at $\mathrm{pH} 7-8$ and $\mathrm{pH} 10$.

(iii) Concentration of BCECF-AM. The cells of C-125 were incubated at $4{ }^{\circ} \mathrm{C}$ for $2.5 \mathrm{~h}$ in $0.1 \mathrm{M} \mathrm{NaCl} / 0.1 \mathrm{M}$ $\mathrm{KCl} / 0 \cdot 1 \%$ glucose $/ 0 \cdot 1 \mathrm{M}$ Tricine $/ \mathrm{NaOH}(\mathrm{pH} 8.5$ ) containing $2-40 \mu \mathrm{M}$ BCECF-AM. The amount of BCECF accumulated by the cells was dependent on the BCECFAM concentration. The BCECF accumulated reached a maximum when the cells were incubated with BCECF$\mathrm{AM}$ at concentrations of $10 \mu \mathrm{M}$ and higher. Half maximal accumulation was found at about $4 \mu \mathrm{M}$ BCECF-AM.

Based upon these results, in subsequent experiments the C-125 cells were loaded with BCECF under the conditions described in Methods. Autolytic enzymes of $B$. lentus $\mathrm{C}-125$ are derepressed by carbon starvation and are active at alkaline $\mathrm{pH}$. The cells are stabilized in the presence of glucose even at alkaline $\mathrm{pH}$ (Aono \& Sanada, 1994). Therefore, we added $0 \cdot 1 \%$ glucose to the buffers to avoid the autolysis of the cells.

\section{Leakage of BCECF from the cells}

It has been reported that BCECF is excreted from Lactococcus lactis cells by ATP-driven extrusion systems (Molenaar et al., 1992). The efflux of BCECF was stimulated upon energization of the cells by addition of lactose. The rate of BCECF leakage from Propionibacterium acnes was dependent on the cytoplasmic and external pH (Futsaether et al., 1993). P. acnes appeared to excrete BCECF in response to $\triangle \mathrm{pH}$. However, BCECF excretion was not increased by addition of glucose to this organism. These reports suggest that micro- 


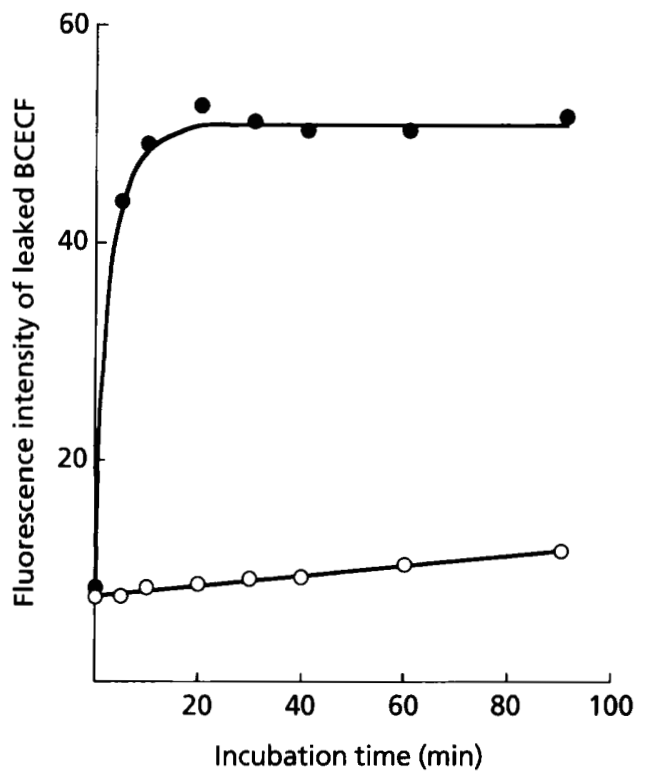

Fig. 1. Leakage of BCECF from the cells. The $\mathrm{C}-125$ cells grown at $37^{\circ} \mathrm{C}$ and $\mathrm{pH} 10$ were loaded with BCECF as described in Methods, and then resuspended in $0.1 \mathrm{M} \mathrm{NaCl} / 0.1 \mathrm{M} \mathrm{KCl} / 0.1 \%$ glucose $/ 0.1 \mathrm{M} \mathrm{CHES} / \mathrm{NaOH} \quad(\mathrm{pH} 9.1)$. The suspension was incubated on ice (O) or at $37^{\circ} \mathrm{C}(0)$. A portion of the suspension was periodically centrifuged. Fluorescence intensity (excitation at $505 \mathrm{~nm}$ and emission at $535 \mathrm{~nm}$ ) of the supernatant diluted fourfold with $0.1 \mathrm{M} \mathrm{CHES} / \mathrm{NaOH}(\mathrm{pH} 9.7$ ) was measured.

organisms differ in their retention of BCECF intracellularly. An excitation spectrum obtained from a cell suspension containing a high concentration of extracellular BCECF reflects not only the intracellular $\mathrm{pH}$ but also the extracellular $\mathrm{pH}$. This effect could produce significant errors in the estimation of the cytoplasmic $\mathrm{pH}$.

Leakage of BCECF from the C-125 cells was examined at $\mathrm{pH} 9 \cdot 1$ (Fig. 1). The leakage was quantified by measurement of fluorescence intensity of extracellular BCECF excited at $505 \mathrm{~nm}$. Extracellular BCECF had an excitation maximum at $505 \mathrm{~nm}$, which was slightly lower than that of the intracellular BCECF, found at $508-510 \mathrm{~nm}$. The rate of BCECF leakage from C- 125 was significantly dependent on the incubation temperature. At $37^{\circ} \mathrm{C}$, leakage was rapid during the first 20 min after resuspension. Intracellular BCECF at this time corresponded to about $50 \%$ of the amount originally loaded. Leakage was extremely slow on ice.

The C-125 cells loaded with BCECF and washed at $37^{\circ} \mathrm{C}$ as described above were adapted to an alternative milieu $\mathrm{pH}$ and further leakage of the residual intracellular BCECF at $37^{\circ} \mathrm{C}$ was examined during the adaptation. Although the cells had ceased to release $\mathrm{BCECF}$ by the end of the preceding wash (Fig. 1), the cells began to release residual BCECF at a slow, roughly constant rate in the fresh buffer. Approximately $10 \%$ of the intracellular BCECF had been excreted $30 \mathrm{~min}$ after resuspension. The BCECF leakage from the $\mathrm{C}-125$ cells was suppressed by gramicidin. The cells were incubated in the presence of glucose to avoid autolysis of the cells which occurs under carbon starvation and were therefore energized throughout the experiments. The organism seems to excrete intracellular BCECF by an energy-dependent extrusion system.

BCECF leakage from bacteria that had been washed once at $37^{\circ} \mathrm{C}$ was slow. This slow rate was desirable when fluorescence intensity of the intracellular BCECF was being monitored because the proportion of extracellular BCECF would remain low. The fluorescence intensity measured could be corrected by the subtraction of that of a supernatant solution obtained from the BCECF-loaded cell suspension because of the slow rate of the BCECF leakage.

\section{Calibration of the fluorescence determination of cytoplasmic pH}

The fluorescence signal of intracellular BCECF must be calibrated by measurements using bacteria of known cytoplasmic $\mathrm{pH}$. Ionophores, such as gramicidin and nigericin, have been used for this purpose to control bacterial cytoplasmic pH (Kitada et al., 1989; Futsaether et al., 1993; Hashimoto et al., 1994; Molenaar et al., 1991).

The fluorescence intensity of intracellular BCECF in the C-125 cells was measured in the presence of gramicidin. Gramicidin functions as an effective carrier for monovalent cations, such as $\mathrm{H}^{+}, \mathrm{Na}^{+}$and $\mathrm{K}^{+}$ions which were abundantly present in the buffers used. This ionophore causes the disappearance of a proton motive force gradient across the cytoplasmic membrane $\left(\Delta \mu \mathrm{H}^{+}\right)$. Accompanying the disappearance of $\Delta \mu \mathrm{H}^{+}$, a $\mathrm{pH}$ gradient across the cytoplasmic membrane $(\Delta \mathrm{pH})$ becomes negligible (Kitada et al., 1989).

Fluorescence intensity of intracellular BCECF increased or decreased rapidly in response to the extracellular $\mathrm{pH}$ after the addition of gramicidin to the cell suspension. Gramicidin did not cause leakage of BCECF. Therefore, the change of fluorescence signals based on alteration of cytoplasmic $\mathrm{pH}$ of the $\mathrm{C}-125$ cells was due to flux of $\mathrm{H}^{+}$ ions in response to extracellular $\mathrm{pH}$ (Fig. 2). The cytoplasmic $\mathrm{pH}$ shown in the figure was calculated as described below. The cells were adapted to the extracellular $\mathrm{pH}$ for $30 \mathrm{~min}$ with or without gramicidin. During this time, an equilibrium between the extracellular and cytoplasmic $\mathrm{pH}$ values was achieved. Theoretically, the cytoplasmic $\mathrm{pH}$ is slightly lower than the extracellular $\mathrm{pH}$ due to a membrane potential $(\Delta \psi)$, when equilibrium across the membrane is established with gramicidin. The presence of a significant $\Delta \psi$ introduces some errors into the estimation of the cytoplasmic $\mathrm{pH}$. However, we found similar cytoplasmic $\mathrm{pH}$ values by using the nigericin-potassium method to eliminate $\Delta \mathrm{pH}$ (results not shown), indicating that the $\Delta \psi$ was not high enough to yield significant errors on measurement of the cytoplasmic $\mathrm{pH}$ of the cells when the $\mathrm{pH}$ equilibrium was accomplished. 


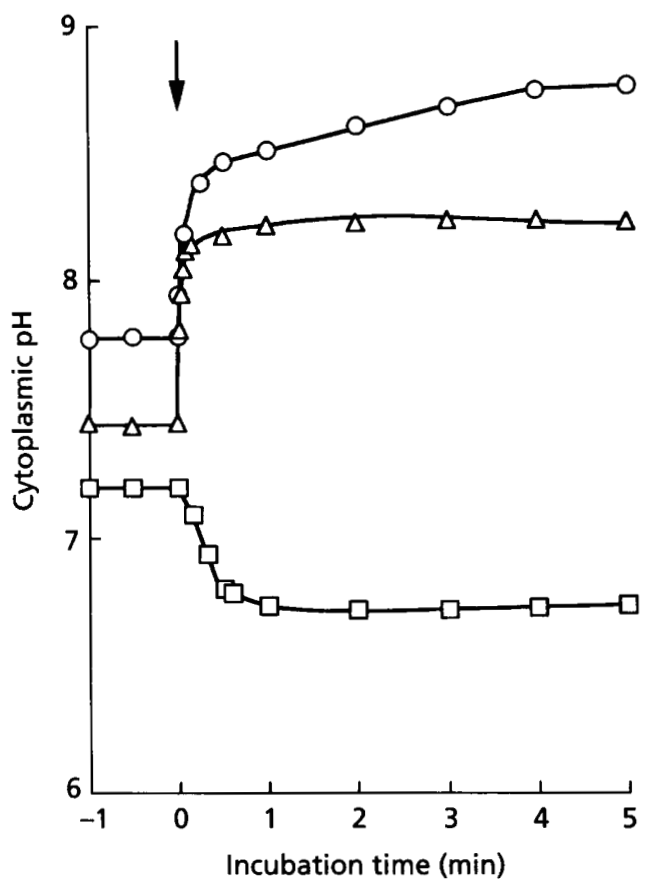

Fig. 2. Changes in cytoplasmic $\mathrm{pH}$ of $\mathrm{C}-125$ cells after treatment with gramicidin. The $\mathrm{C}-125$ cells grown at $\mathrm{pH} 10$ and loaded with BCECF were resuspended in TES-buffered $0.1 \mathrm{M} \mathrm{NaCl} / 0.1 \mathrm{M}$ $\mathrm{KCl} / 0.1 \%$ glucose with $\mathrm{pH}$ values of $6.7(\square), 8.2(\triangle)$ or $8.8(O)$. At 0 min (indicated by an arrow), $20 \mu \mathrm{M}$ gramicidin was added. The $F_{510}$ of the intracellular BCECF was monitored and used to calculate cytoplasmic pH as described in Results.

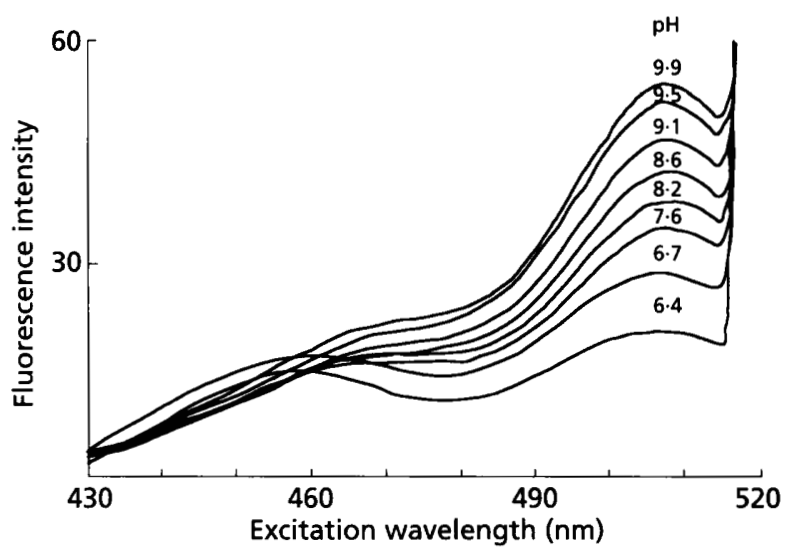

Fig. 3. Excitation spectra of the $\mathrm{C}-125$ cells loaded with $\mathrm{BCECF}$ and washed by incubation in $0.1 \mathrm{M} \mathrm{NaCl} / 0.1 \mathrm{M} \mathrm{KCl} / 0.1 \%$ glucose $/ 0.1 \mathrm{M} \mathrm{CHES} / \mathrm{NaOH}(\mathrm{pH} 9.1)$ at $37^{\circ} \mathrm{C}$ for $45 \mathrm{~min}$. The cells were then incubated in $0.1 \mathrm{M}$ TES or glycine buffer $(\mathrm{pH} 6.4-9.9)$ containing $0.1 \mathrm{M} \mathrm{NaCl} / 0.1 \mathrm{M} \mathrm{KCl} / 0.1 \%$ glucose $/ 20 \mu \mathrm{M}$ gramicidin at $37^{\circ} \mathrm{C}$ for $30 \mathrm{~min}$. Fluorescence intensity (excitation at $430-520 \mathrm{~nm}$ and emission at $535 \mathrm{~nm}$ ) of the suspension was recorded.

Fig. 3 shows a typical set of fluorescence excitation spectra of the C-125 cells loaded with BCECF and exposed to various $\mathrm{pH}$ values in the presence of gramicidin. The C-125 cells contained an unidentified fluorescent substance with an excitation maximum of

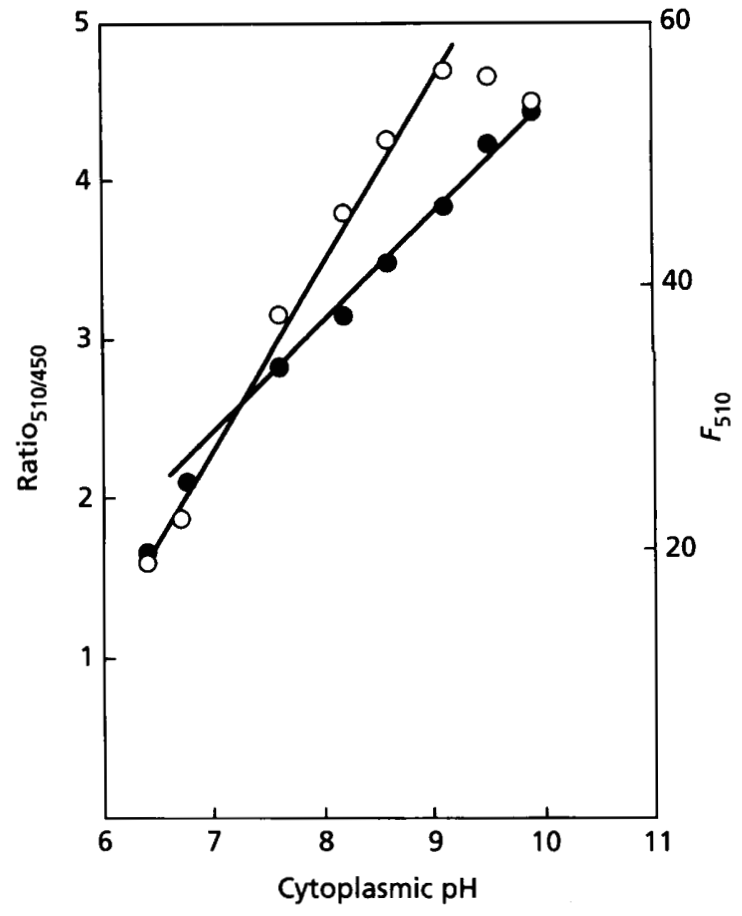

Fig. 4. Correlation between fluorescence signals of intracellular BCECF and cytoplasmic $\mathrm{pH}$ of $\mathrm{C}-125$ cells. Parameters of Ratio $_{510 / 450}(O)$ and $F_{510}$ (O) were calculated from the fluorescence excitation spectra shown in Fig. 3.

$460 \mathrm{~nm}$ and, therefore, the profile of the excitation spectrum of the suspension varied according to the BCECF concentration in the cells. An isosbestic point was not clear in the spectra. The dye could not be used as a dual-excitation $\mathrm{pH}$ indicator under these conditions. When the cytoplasmic $\mathrm{pH}$ was fixed at the extracellular $\mathrm{pH}$ in the presence of gramicidin, two parameters of spectra (Ratio ${ }_{510 / 450}$ and $F_{510}$ of BCECF) correlated with the cytoplasmic pH (Fig. 4). The Ratio ${ }_{510 / 450}$ gave good correlation with the cytoplasmic $\mathrm{pH}$ between 6.4 and 9.1. It was reported that a similar ratio (intensities at 505 and $450 \mathrm{~nm}$ ) correlated with cytoplasmic $\mathrm{pH}$ (below $\mathrm{pH} 8$ ) in $P$. acnes (Futsaether et al., 1993). The $F_{510}$ correlated with the $\mathrm{pH}$ from $7 \cdot 6$ to $9 \cdot 9$.

\section{Measurement of cytoplasmic pH and the culture-pH- dependent cytoplasmic $\mathrm{pH}$ maintenance activity of C-125 cells}

We used the two fluorescence calibration curves shown in Fig. 4 to measure cytoplasmic pH of C-125. By using the two parameters, the cytoplasmic $\mathrm{pH}$ was measured over the range of cytoplasmic $\mathrm{pH} 6-10$. The calibration curves were constructed for each batch of the cell suspension, because each profile of the two calibration curves was somewhat dependent on the BCECF content in the cells, as described above.

B. lentus $\mathrm{C}-125$ cells grown at a constant $\mathrm{pH}(7 \cdot 0,8 \cdot 5$ or $10 \cdot 0)$ and loaded with BCECF were exposed to buffers in the $\mathrm{pH}$ range $6-12$ (Fig. 5). The cytoplasmic $\mathrm{pH}$ of the cells grown at $\mathrm{pH} 10$ was almost constant at a wide 


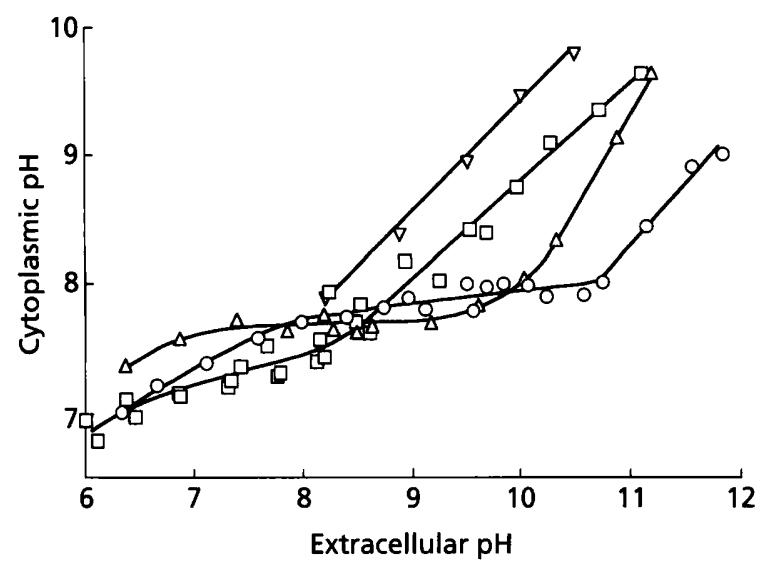

Fig. 5. Cytoplasmic $\mathrm{pH}$ of $\mathrm{C}-125$ cells as a function of the extracellular $\mathrm{pH}$. B. lentus $\mathrm{C}-125$ was grown at $\mathrm{pH} 7.0$ ( $\square$ ), 8.5 $(\triangle)$ or $10.0(O)$. B. subtilis GSY1026 $(\nabla)$ was grown at $\mathrm{pH} 7.0$ and used as a reference strain. The cells in the stationary phase of growth were loaded with BCECF and washed as described in Fig. 3. The cells were incubated for $30 \mathrm{~min}$ in $0.1 \mathrm{M}$ TES or glycine buffer containing $0.1 \mathrm{M} \mathrm{NaCl} / 0.1 \mathrm{M} \mathrm{KCl} / 0.1 \%$ glucose at various $\mathrm{pH}$ values. Measurement of fluorescence intensity of the intracellular BCECF is detailed in Methods. Cytoplasmic pH of the cells was calculated mainly from the Ratio ${ }_{510 / 450}$. The $\mathrm{pH}$ above 9 was calculated from $F_{510}$.

range of extracellular $\mathrm{pH}$ values. Over the range $\mathrm{pH} 7 \cdot 0-10.7$ which was the physiological $\mathrm{pH}$ range for the organism, the cytoplasmic $\mathrm{pH}$ was maintained at $7 \cdot 2-8 \cdot 0$ under the experimental conditions. At $\mathrm{pH}$ above $10 \cdot 7$, the organism lost its $\mathrm{pH}$ homeostatic activity. $B$. lentus $\mathrm{C}-125$ does not grow at $\mathrm{pH}$ above 10.8 (Aono et al., 1995).

The cells grown at $\mathrm{pH} 7 \cdot 0$ maintained neutral cytoplasmic $\mathrm{pH}(\mathrm{pH} 7-8)$ only when exposed to an external $\mathrm{pH}$ below 9. Above 9, cytoplasmic $\mathrm{pH}$ increased much more than in bacteria grown at $\mathrm{pH} 10 \cdot 0$. The cytoplasmic $\mathrm{pH}$ of cells exposed to $\mathrm{pH} 10.5$ was $9 \cdot 3$. This $\mathrm{pH}$ value was one unit higher than that of the cells grown at $\mathrm{pH} 10 \cdot 0$ and exposed to $\mathrm{pH} 10 \cdot 5$. Thus, the $\mathrm{pH}$ homeostatic activity of the cells grown at $\mathrm{pH} 7.0$ was low, although higher than that of a neutrophilic microorganism, B. subtilis GSY1026. The intracellular $\mathrm{pH}$ of $\mathrm{C}-125$ grown at $\mathrm{pH} 7$ became sensitive to extracellular $\mathrm{pH}$ above $8 \cdot 5$, whereas that of $B$. subtilis GSY1026 became sensitive when exposed to an extracellular $\mathrm{pH}$ above $8 \cdot 2$ (Fig. 5). B. subtilis GSY1026 does not grow at $\mathrm{pH}$ values above 8.5 (Aono et al., 1996). The cytoplasmic $\mathrm{pH}$ of $\mathrm{C}-125$ was about $7 \cdot 2$ at the extracellular $\mathrm{pH}$ of around 7 .

When $\mathrm{C}-125$ was grown at $\mathrm{pH} 8 \cdot 5$, the $\mathrm{pH}$ homeostatic activity was intermediate between those of the bacteria grown at $\mathrm{pH} 7 \cdot 0$ and $10 \cdot 0$. Cytoplasmic $\mathrm{pH}$ of the cells grown at $\mathrm{pH} 8.5$ and exposed to $\mathrm{pH}$ below 10 was maintained neutral ( $\mathrm{pH} 7-8$ ). The cytoplasm became more alkaline when the cells were exposed to $\mathrm{pH}$ above 10. These results indicated that the culture $\mathrm{pH}$ determined the upper limit of the extracellular $\mathrm{pH}$ against which the cytoplasmic $\mathrm{pH}$ could be maintained neutral.

\section{DISCUSSION}

The cytoplasmic $\mathrm{pH}$ of another facultative alkaliphile, Bacillus firmus OF4, was reported to be $7 \cdot 5-8 \cdot 3$ when the organism was grown at $\mathrm{pH} 7 \cdot 5-10 \cdot 5$ (Sturr et al., 1994). The cytoplasmic $\mathrm{pH}$ of $\mathrm{C}-125$ measured by the fluorescence intensity of BCECF was similar to and slightly lower than the values reported for OF4. The cytoplasmic $\mathrm{pH}$ of $\mathrm{C}-125$ grown at initial $\mathrm{pH}$ of 10.5 and exposed to $\mathrm{pH} 10.5$ was previously reported to be 8.64 (Hashimoto et al., 1994). This $\mathrm{pH}$ value was measured after prolonged incubation of the cells without any carbon source. We feel that this value was not physiologically significant. The value is likely to have been overestimated, probably due to autolysis or to deenergization caused by carbon starvation.

We have shown that the cytoplasmic $\mathrm{pH}$ of the alkaliphile can be measured by fluorescence intensity of BCECF loaded under the conditions described here. Cytoplasmic $\mathrm{pH}$ values of alkaliphiles have previously been determined from the distribution of weak acids or weak bases (Sugiyama et al., 1985; Kitada et al., 1989; Hashimoto et al., 1994; Sturr et al., 1994). This method assumes that only uncharged molecules of the electrolytes can pass through the biological membrane (Padan \& Schuldiner, 1986). Alkylamines have been applied to alkaliphiles (inside acidic) exposed to high alkaline $\mathrm{pH}$. $\mathrm{p} K_{\mathrm{a}}$ values of these amines are in the range of 10-11. The distribution method using the amines is therefore most appropriate for determination of cytoplasmic $\mathrm{pH}$ in alkaliphiles exposed to $\mathrm{pH}$ below 9. Experimental errors would increase with increasing external $\mathrm{pH}$. An amine with $\mathrm{p} K_{\mathrm{a}}$ of 13-14 would be needed to determine the cytoplasmic $\mathrm{pH}$ of $\mathrm{C}-125$ cells exposed to high alkaline $\mathrm{pH}$, such as 11-12. Such an amine is not available. In addition, cytoplasmic $\mathrm{pH}$ is determined following equilibration of the electrolyte between the inside and outside of the cells. At a much higher $\mathrm{pH}$ than the $\mathrm{p} K_{\mathrm{a}}$ of the amine used, few molecules are uncharged and permeable through the membrane. The rapid changes of cytoplasmic $\mathrm{pH}$ shown in Fig. 2 would be very difficult to follow by the distribution method.

The cytoplasmic $\mathrm{pH}$ has also been measured from fluorescence quenching of 9-aminoacridine (Tsuchiya \& Takeda, 1979; Sugiyama et al., 1985; Kitada et al., 1994). This pigment is retained effectively in cells whose cytoplasmic $\mathrm{pH}$ is lower than the extracellular $\mathrm{pH}$. C-125 grows at a relatively wide range of extracellular $\mathrm{pH}$ and its cytoplasmic $\mathrm{pH}$ is not always lower than the extracellular $\mathrm{pH}$ (Fig. 5). The pigment is thus not appropriate for measurement of cytoplasmic $\mathrm{pH}$ in $\mathrm{C}-125$ exposed to neutral extracellular $\mathrm{pH}$.

$\mathrm{pH}$ measurement on the basis of fluorescence intensity of intracellular BCECF can provide real-time information about the cytoplasmic $\mathrm{pH}$. This method is useful for analysing the pH-homeostatic activity of alkaliphiles. However, a disadvantage of the method is the need to use stationary-phase bacteria which are incu- 
bated at $4{ }^{\circ} \mathrm{C}$ and $\mathrm{pH} 9$ to load BCECF and then washed at $37^{\circ} \mathrm{C}$ to excrete excess BCECF (Fig. 1). This might prevent measurement of the cytoplasmic $\mathrm{pH}$ under normal physiological conditions. However, it was shown that the $\mathrm{pH}$-homeostatic activity of C-125, measured in this study, was closely related to the growth $\mathrm{pH}$. These results suggested that the physiologically normal cytoplasmic $\mathrm{pH}$ could be measured in spite of the unfavourable procedures.

It is well known that alkaliphiles growing in alkaline milieu maintain a neutral cytoplasmic $\mathrm{pH}$ (Sturr et al., 1994; Krulwich, 1995). The facultative alkaliphile, $\mathrm{C}-125$, developed this $\mathrm{pH}$ maintenance activity in response to the culture $\mathrm{pH}$. The organism can grow in complex medium at $\mathrm{pH} 6 \cdot 8-10 \cdot 8$ with the optimum $\mathrm{pH}$ for growth at 9 (Aono et al., 1995). Probably due to some regulation of the $\mathrm{pH}$-homeostatic activity level, the cytoplasm of the organism is always kept neutral ( $\mathrm{pH} 7-8$ ) regardless of the culture $\mathrm{pH}$. Although the cytoplasmic $\mathrm{pH}$ measured in this study was not strictly that of the growing cells, the cytoplasmic $\mathrm{pH}$ values of the cells growing at $\mathrm{pH} 7 \cdot 0,8.5$ and 10.0 were estimated to be $7 \cdot 2,7 \cdot 7$ and $8 \cdot 0$, respectively (Fig. 5).

The maintenance of $\mathrm{pH}$ is likely to be energy-dependent because the cytoplasmic $\mathrm{pH}$ of the $\mathrm{C}-125$ cells exposed to alkaline $\mathrm{pH}$ was elevated by treatment with $\mathrm{KCN}$ or antimycin (results not shown). These chemicals inhibit respiratory activity of $\mathrm{C}-125$. The respiratory activity of B. lentus $\mathrm{C}-125$ is dependent on the culture $\mathrm{pH}$ (Aono et al., 1996). The organism possesses $\Delta \psi$ - and $\Delta \mathrm{pH}$ dependent $\mathrm{Na}^{+} / \mathrm{H}^{+}$antiport systems. The former antiporter activity increases with increasing culture $\mathrm{pH}$ (Kitada et al., 1994). Further, anionic charges fixed in the cell walls also increase with increasing culture $\mathrm{pH}$ (Aono et al., 1995). The cell-wall density of the charges is 2,6 or $8 \mu \mathrm{mol}$ (mg peptidoglycan) ${ }^{-1}$ in the cells grown at $\mathrm{pH} 7.0,8.5$ or 10.0 , respectively. These facts are consistent with the result that the cytoplasmic $\mathrm{pH}$ maintenance activity was developed in response to the culture $\mathrm{pH}$. We presume that $\mathrm{pH}$ homeostasis of $\mathrm{C}-125$ involves several functions of the organism.

\section{ACKNOWLEDGEMENTS}

This work was partially supported by a grant for 'Biodesign Research Program' from RIKEN to R. Aono.

\section{REFERENCES}

Aono, R. (1985). Isolation and partial characterization of structural components of the walls of alkalophilic Bacillus strain C125. J Gen Microbiol 131, 105-111.

Aono, R. (1995). Assignment of facultatively alkaliphilic Bacillus sp. C-125 to Bacillus lentus group 3. Int J Syst Bacteriol 45, 582-585.

Aono, R. \& Horikoshi, K. (1983). Chemical composition of cell walls of alkalophilic strains of Bacillus. J Gen Microbiol 129, 1083-1087.

Aono, R. \& Sanada, T. (1994). Hyper-autolysis of the facultative alkaliphile Bacillus sp. C-125 cells grown at neutral $\mathrm{pH}$ : culture-
$\mathrm{pH}$-dependent cross-linking of the peptide moieties of the peptidoglycan. Biosci Biotechnol Biochem 58, 2015-2019.

Aono, R., Ito, M., Joblin, K. N. \& Horikoshi, K. (1995). A high cell wall negative charge is necessary for the growth of the alkaliphile Bacillus lentus C-125 at elevated pH. Microbiology 141, 2955-2964.

Aono, R., Kaneko, H. \& Horikoshi, K. (1996). Alkaline growth pHdependent increase of respiratory and NADH oxidation activities of facultatively alkaliphilic strain Bacillus lentus C-125. Biosci Biotechnol Biochem 60, 1243-1248.

Dencher, N. A., Burghaus, P. A. \& Grzesiek, S. (1986). Determination of the net proton-hydroxide ion permeability across vesicular lipid bilayers and membranes proteins by optical probes. Methods Enzymol 127, 746-760.

Futsaether, C. M., Kjeldstad, B. \& Johnsson, A. (1993). Measurement of the intracellular $\mathrm{pH}$ of Propionibacterium acnes: comparison between the fluorescent probe BCECF and ${ }^{31} \mathrm{P}$ NMR spectroscopy. Can J Microbiol 39, 180-186.

Hashimoto, M., Hamamoto, T., Kitada, M., Hino, M., Kudo, T. \& Horikoshi, K. (1994). Characteristics of alkali-sensitive mutants of alkaliphilic Bacillus sp. strain C-125 that show cellular morphological abnormalities. Biosci Biotechnol Biochem 58, 2090-2092.

Kitada, M., Onda, K. \& Horikoshi, K. (1989). The sodium/proton antiport system in a newly isolated alkalophilic Bacillus sp. $J$ Bacteriol 171, 1879-1884.

Kitada, M., Hashimoto, M., Kudo, T. \& Horikoshi, K. (1994). Properties of two different $\mathrm{Na}^{+} / \mathrm{H}^{+}$antiport systems in alkaliphilic Bacillus sp. strain C-125. J Bacteriol 176, 6464-6469.

Krulwich, T. A. (1995). Alkaliphiles: 'basic' molecular problems of $\mathrm{pH}$ tolerance and bioenergetics. Mol Microbiol 15, 403-410.

Miller, J. H. (1972). Experiments in Molecular Genetics. Cold Spring Harbor, NY: Cold Spring Harbor Laboratory.

Molenaar, D., Abee, T. \& Konings, W. N. (1991). Continuous measurement of the cytoplasmic $\mathrm{pH}$ in Lactococcus lactis with a fluorescent $\mathrm{pH}$ indicator. Biochim Biophys Acta 1115, 75-83.

Molenaar, D., Bolhuis, H., Abee, T. \& Konings, W. N. (1992). The efflux of a fluorescent probe is catalyzed by an ATP-driven extrusion system in Lactococcus lactis. J Bacteriol 174, 118-124.

Padan, E. \& Schuldiner, S. (1986). Intracellular pH regulation in bacterial cells. Methods Enzymol 125, 337-352.

Sturr, M. G., Guffanti, A. A. \& Krulwich, T. A. (1994). Growth and bioenergitics of alkaliphilic Bacillus firmus OF4 in continuous culture at high pH. J Bacteriol 176, 3111-3116.

Sugiyama, S., Matsukura, H. \& Imae, Y. (1985). Relationship between $\mathrm{Na}^{+}$-dependent cytoplasmic $\mathrm{pH}$ homeostasis and $\mathrm{Na}^{+}$dependent flagella rotation and amino acid transport in alkalophilic Bacillus. FEBS Lett 182, 265-268.

Tsuchiya, T. \& Takeda, K. (1979). Calcium/proton and sodium/ proton antiport systems in Escherichia coli. J Biochem 85, 943-951.

Tsujimoto, K., Semadeni, M., Huflejt, M. \& Packer, L. (1988). Intracellular $\mathrm{pH}$ of halobacteria can be determined by the fluorescent dye 2',7'-bis-(2-carboxyethyl)-5(6)-carboxyfluorescein. Biochem Biophys Res Commun 155, 123-129.

Zilverstein, D., Agmon, V., Schuldiner, S. \& Padan, E. (1982). The sodium/proton antiporter is part of the $\mathrm{pH}$ homeostasis mechanism in Escherichia coli. J Biol Chem 257, 3687-3691.

Received 26 November 1996; revised 13 March 1997; accepted 6 May 1997. 